\title{
2. THE ROLE OF FINE ARTS ACTIVITY IN THE DEVELOPMENT OF ARTISTIC THINKING OF SCHOOLCHILDREN
}

Aliona Brițchi 201

\begin{abstract}
This article deals with the development of artistic and imaginative thinking, imagination and the creation of an artistic image in fine arts lessons using a graphic image. An example of a lesson for elementary school students on creating a mysterious tree image is given, which will help the teacher develop the ability of his students to see and creatively realize their ideas.
\end{abstract}

Key words: artistic-figurative thinking, artistic image, visual activity, imagination, graphics, line, contour, spot, primary school students

\section{Introduction}

The task of educating a person who thinks outside the box, who is able to cope with the problems that life poses to him, can be solved as a result of a more complete disclosure of the creative potential of the individual, in particular through the development of artistic and imaginative thinking in the process of visual activity.

The modern education system requires the student to have a high level of proficiency in both educational, theoretical and visual activities (graphic, painting, decorative, etc.). However, schools, as a rule, set themselves the task of producing students who can read, write, and count well, and they forget that the child must be aesthetically developed. Many graduates are not interested in works of classical art, do not understand music, theater, literature, art. They do not understand the language of artistic-figurative systems, i.e. any work of art (musical, literarypoetic, pictorial, choreographic, theatrical), created according to the laws of artistic creation.

Unfortunately, in general education schools, not enough attention is paid to the development of artistic-figurative thinking, in contrast to abstract-logical thinking, meanwhile, it is very important to form artistic-figurative thinking in children from elementary school in fine arts lessons. In these lessons, the child can learn in his own way, to look at the phenomena of the surrounding world and thus feel more deeply his spiritual world.

\section{Artistic image and graphics}

The artistic image is a form of reflecting reality and expressing the thoughts and feelings of the artist, specific to art. The image is born in his imagination, is embodied in one or another material form in the created work and is recreated by the imagination of the viewer, reader, listener who perceives the art. The artistic image is a complex unity of objective and subjective, logical and sensual, rational

\footnotetext{
201 Associate Professor PhD, "Alecu Russo" State University from Bălți, Republic of Moldova, email:
} alionabritchi@mail.ru 
and emotional, content and form. On the basis of such a fusion, expressed by means specific for each type of art, images-characters, images-events, imagesdetails are created that convey certain aesthetic ideas and feelings.

For example, in graphics, the main means of expression are a line, stroke, contour or spot on a white sheet of paper, with the help of which the artist can create character images. One of the artist's tasks is to achieve the vitality of a real impression by these means, to convey the completeness of a holistic image. Graphics is the kind of visual art that is available to students of any age. Close to painting in terms of content and form, it has its own specific tasks and artistic possibilities. The limited role of color allows you to work with felt-tip pens (so beloved by the students for brightness and convenience), graphite pencils, charcoal, sanguine, pastels or an ordinary pen. In this case, watercolors and gouache play a supporting role.

Graphic images are close and understandable to younger students, since in their daily life and in the learning process they have to constantly deal with texts, illustrations in books, reproductions. Based on the drawing with strokes and lines, a graphic image is most acceptable for children's perception, since it emphasizes the characteristic features of objects and omits minor ones.

\section{Creation of an artistic image in fine arts lessons}

For the development of artistic and imaginative thinking and imagination in junior students, I propose to conduct the following lesson.

Lesson topic: „The Mysterious Image of a Tree”

The purpose of the lesson: the formation of skills in transferring the image of a tree using graphic means.

\section{Lesson objectives:}

\section{Cognitive:}

- to form the ability to establish the relationship between two types of art (graphic and poetic);

- expand the horizons of students, fantasy, imagination;

- reflect the received impressions in creative works;

\section{Developing:}

- develop the ability to see, hear, understand and feel the beautiful in the surrounding nature;

- arouse students' interest in the fairy-tale image, the desire to convey it in a graphic form;

\section{Educational:}

- to educate emotional responsiveness to aesthetic phenomena in nature; accuracy and diligence;

- critical attitude to the results of their activities.

Materials and equipment: pastel paper (light shade), pencil, charcoal, sanguine, eraser.

\section{During the classes.}

\section{Organizational moment}

Preparing students for the lesson. Organization of the workplace. The teacher 
informs the children that today they will make a journey into the kingdom of trees, learn about the features of their graphic image.

\section{Theoretical part}

The teacher shows reproductions and photographs of trees.

Teacher:

- Look, the trees look alike only at first glance, but if you look more closely, you will see that each of them has its own unique appearance, just like you and me. Why are trees compared to people, how are they similar?

Students note that the trunk is like a human body, the roots are like the legs, the crown is like the head, the branches are like the arms.

- Some trees are thin, fragile, slender, similar to ... (girls). Others are powerful, strong, stand strong branches to the sky, as if they greet the sun, similar to ... (men).

The teacher's story (against the background of a musical splash).

- Once the artist went on a long journey. How long or short he walked, but finally he reached the kingdom where only trees lived. Here he was greeted by three heroic trees with straight like an arrow trunks and asked:

- Why did you come to us, artist?

- To see the world and learn to wits, - he replied.

- For a long time a human foot has not set foot in our kingdom. If you come in peace, come in.

The giant trees parted their branches, the artist entered the forest and saw fantastic trees ... And now each of you imagine that you have turned into these fantastic trees. Try to fantasize, imagine how you might look like a tree, each in your own way, and paint your own portrait.

\section{The practical part}

\section{Explanation of the teacher:}

- Today we work with soft materials - coal and sanguine, they are very fragile, so be careful. They can draw different lines (if you work with an edge, you get a thin line, if flat, then thick).

Children practice drawing lines and strokes.

- We start drawing the tree from the roots, then we draw the trunk, branches, crown. After we have drawn the silhouette of the tree, we proceed to decorate it.

\section{Independent work of students.}

The teacher helps to clarify the size and shape of trees, decorations.

\section{Lesson summary}

Analysis of the work performed by students; exhibition of drawings.

- How do you feel when you look at these trees? Who do they remind you of? Our journey into the kingdom of trees has come to an end. What have you learned today? (To experience unity with nature, to feel it in oneself, to see beauty, etc.).

\section{Conclusions}

The ability to choose independently the version of the image and artistic means stimulates creative thought, memory, imagination and observation, develops imagination, forms the student's artistic thinking. The task of the teacher is to 
develop in his students the ability to see and consider the shape of an object from different points, to be able to convey it on the pictorial plane, to develop a sense of space, to teach them creatively approach the image of surrounding objects, phenomena and events. While drawing, the younger student learns the surrounding reality more deeply, feels more vividly and notices more, develops visual memory, imaginative thinking, fine motor skills of the hand, learns to highlight the essential features of objects, their shape and structure, and understand harmony and beauty.

\section{References}

1. Arbuz-Spatari O., Dezvoltarea creativității artistice la studenți în cadrul cursului de artă textilă: ghid metodologic/Arbuz-Spatari O., Simac A.: Chisinau, Garomond Studio, 2012. - $250 \mathrm{p}$

2. Britchi Aliona, Didactics of Plastic Education, Balti, Indigou Color, 2020

3. Cristea Maria, Didactics of teaching Plastic Education to primary grades, Bucuresti, Corint, 2009

4. Ciubotaru S., Ciubotaru I. Ornamente populare tradiţionale din Moldova (cusături, țesături). Iasi: „Al. I.Cuza”University; Centre of linguistics, Literary History and Folklore, the Folklore Archive of Moldovei and Bucovina, 1988. 337

$\mathrm{p}$

5. Chevalier J. Gheerbrant A. Dicţionar de simboluri vol. I, II, III. Bucharest: Artemis, 1994. $503 \mathrm{p}$

6. Dicţionar de artă. Forme, tehnici, stiluri artistice. Vol. I, II. Bucharest: Meridiane, 1998. $188 \mathrm{p}$

7. Dumitrescu Z., Structuri geometrice structuri plastice. Buc: Meraresidiane 1984. $221 \mathrm{p}$

8. Dunăre N. Ornamentica tradiţională comparată. Bucharest: Meridiane,1979. $159 \mathrm{p}$

9. Mureşean D. Cunoaşterea şi creaţia artistică cu referiri speciale la artele plastice. Bucharest: Cybela, 2000. $110 \mathrm{p}$

10. Prut C. Calea rătăcită. O privire asupra artei populare româneşti. Bucharest: Meridiane, 1991. $159 \mathrm{p}$

11. Vasilescu V. Semnele cerului. Cultură şi civilizaţie carpatică. Iasi: Arhetip- Renaşterea Spirituală, 1993. 214 p 